\title{
EVALUASI SISTEM IRIGASI TERSIER PADA DAERAH IRIGASI MENINTING DI DESA JATISELA KECAMATAN GUNUNG SARI KABUPATEN LOMBOK BARAT
}

\author{
Budy Wiryono $^{1 *}$, Suwati ${ }^{2}$, Marianah 3 \\ ${ }^{1}$ Teknik Pertanian, Universitas Muhammadiyah Mataram, budyui@gmail.com* \\ 2,TeknikPertanian, Universitas Muhammadiyah Mataram \\ ,3Teknologi Hasil Pertanian, Universitas Muhammadiyah Mataram
}

\section{INFO ARTIKEL}

RiwayatArtikel:

Diterima: 17 -07-2017

Disetujui: 20-08-2017

\section{Kata Kunci:}

Evaluasai

Irigasi tersier

Jaringan Irigasi

\begin{abstract}
ABSTRAK
Abstrak:Penelitian yang berjudul "Evaluasi Sistem Irigasi Tersier pada Daerah Irigasi Meninting Di Desa Jatisela Kecamatan Gunung Sari Kabupaten Lombok Barat” bertujuan untuk mengetahui dampak teknis, ekonomi, dan sosial dari jaringan irigasi serta mengetahui kondisi jaringan irigasi tersier di Desa Jatisela Kecamatan Gunung Sari Kabupaten Lombok Barat.

Metode yang digunakan dalam penelitian ini adalah diskriptif dengan metode survey dengan melakukan pengamatan langsung. Penelitian dilaksankan pada bulan Agustus - Nopember 2015. Penelitian deskriptif yang bersifat kualitatif ini dilakukan di lapangan dengan mengamati secara langsung proses Evaluasi Sistem irigasi dan drainase pada daerah irigasi meninting yang selanjutnya hasilnya dianalisis secara tabulasi.

Hasil penelitian ini menunjukkan Secara teknis dilokasi penelitian tidak ada bangunan pembagi air irigasi, debit air sangat rendah sebesar $0,101 \mathrm{~m} / \mathrm{s}$, dan terdapat sistem distirbusi air yang dilakukan oleh $\mathrm{P}_{3} \mathrm{~A}$. Hasil lain, dampak ekonomi sebesar $57 \%$ responden mengakui memperoleh keuntungan dengan keberadaan irigasi. Keuntungan yang di peroleh mencapai 11 juta dalam setiap panen. Selanjutnya secara sosial terdapat peran petani dalam memelihara saluran, kelembagaan petani sangat kuat, dan tingkat partisipasi meningkat. Akhirnya, ditemukan distribusi air yang tidak merata disebabkan karena adanya jaringan irigasi yang rusak dan pemeliharaan yang kurang baik.
\end{abstract}

\section{A. LATAR BELAKANG}

Dalam upaya sumber daya pangan, kesiapan sarana dan prasarana dari pengairan pertanian sangat di butuhkan.Salah satu sarana dan prasarana yang di lakukan adalah dalam hal pengelolaan air menggunakan irigasi.

Sektor pengembangan dan pengelolaan irigasi Nusa Tenggara Barat (NTB) pada 2006 mengalami peningkatan pada 2007 NTB menghasilkan Rp.80,5 miliar dari pengembangan dan pengelolaan irigasi. Jumlah tersebut meningkat sebesar 9,6\% sehingga menjadi 87,7 miliar pada tahun ini. Salah satu indikator keberhasilan pengelolaan padi SRI di NTB di akibatkan oleh pengembangan dan pengelolaan irigasi melalui rehabilitasi daerah irigasi [1].

Permasalahan yang lain muncul yakni keberadaan irigasi sehingga dapat mengetahui kerja irigasi namun menyebabkan masalah baru. Masalah baru yang di maksud adalah kurangnya kesadaran petani dalam pemanfaatan dan pemeliharaan jaringan irigasi, sehingga mengakibatkan luapan air (banjir) di sekitar area persawahan bila terjadi hujan yang besar dampak akhirnya adalah gagal panen.

Begitu juga yang terjadi di Desa Jatisela Kecamatan Gunung Sari. Luas irigasi di daerah ini sepanjang 95101,o Ha. Irigasi di Desa Jatisela mulai di bangun pada tahun 1986 yang bertujuan untuk menyediakan air bagi petani dalam melakukan penanaman [2].

Luas Desa Jatisela saat ini berkisar $261 \mathrm{Ha}$ sedangkan luas sawah lahan pertanian mencapai $132 \mathrm{Ha}$ dan sawah beririgasi sekitar 95-101 Ha, sedangkan irigasi semi teknis mencapai $37 \mathrm{Ha}$ [3].

Kondisi riil yang terjadi terhadap keberadaan irigasi sangat di perlukan untuk melihat besarnya perawatan dan tindakan yang akan di lakukan dalam membuat solusi alternatif. Berkaitan dengan hal tersebut maka akan dilakukan penelitian tentang "Evaluasi Sistem Irigasi Pada Daerah Irigasi Meninting Desa Jatisela Kecamatan Gunung Sari Kabupaten Lombok Barat ".

Penelitian ini bertujuan untuk mengetahui dampak teknis, ekonomi, dan sosial dari jaringan irigasi serta mengetahui kondisi jaringan irigasi tersier di Desa Jatisela Kecamatan Gunung Sari Kabupaten Lombok Barat.

\section{B. METODE PENELITIAN}

Metode yang digunakan dalam penelitian ini adalah diskriptif bersifat kualitatif dengan melakukan survey/pengamatan langsung.Penelitian dilaksankan pada bulan Agustus - Nopember 2015.Pengambilan responden dilakukan secara random sampling yaitu pengambilan sampel secara acak untuk memudahkan penelitian dalam penentuan responden serta mendapatkan hasil penelitian yang akurat.Penentuan responden yang dimaksud dalam penelitian ini adalah yang melakukan usaha pemeliharaan irigasi sampai dengan tahun 2015 sebanyak 30 orang.

Penelitian deskriptif yang bersifat kualitatif ini dilakukan di lapangan dengan mengamati secara langsung proses evaluasi sistem irigasi pada daerah 
irigasi meninting yang selanjutnya hasilnya dianalisis secara tabulasi dan dideskripsikan.

\section{HASIL DAN PEMBAHASAN}

\subsection{Kondisi Irigasi di Desa Jatisela}

Dalam mengamati kondisi irigasi maka dilakukan wawancara untuk memperoleh pernyataan petani secara kualitatif.Dari hasil wawancara diperoleh bahwa sistem pembagian air irigasi diakui masih masih kurang merata dalam pendistribusian air, biasanya terdapat ketidak puasan terhadap distribusi air irigasi untuk usahatani.Ketidak merataan tersebut disebabkan oleh jaringan irigasi yang dibangun ada yang telah rusak sehingga air lebih banyak hilang melalui perembesan atau kebocoran.Selain itu juga masih ada petani yang memanfaatkan air irigasi untuk keperluan memandikan sapi atau hewan lainnya dan air yang mengalir kebanyakan sampah yang mengikuti air.

Selanjutnya, sistem jaringan irigasi dan drainase di suatu kawasan sudah semestinya dirancang untuk menampung debit aliran yang normal, terutama pada saat musim hujan. Artinya kapasitas saluran drainase sudah diperhitungkan untuk dapat menampung debit air yang terjadi sehingga kawasan yang dimaksud tidak mengalami genangan atau banjir. Jika kapasitas sistem saluran drainase menurun dikarenakan oleh berbagai sebab maka debit yang normal sekalipun tidak akan bisa ditampung oleh sistem yang ada. Sedangkan sebab menurunnya kapasitas sistem antara lain, banyak terdapat endapan, terjadi kerusakan fisik sistem jaringan, adanya bangunan lain di atas sistem jaringan.

Indikator ini menunjukkan bahwa tingkat ketersediaan air di saluran tersier maupun kwarter dan cara pengguna air pada lahan sawah irigasi. Komponen yang di pengaruhi oleh kondisi fisik baik lahan sawah maupun irigasinya, dapat di antisipasi oleh petugas irigasi (ulu-ulu atau juru pintu) dengan cara pembagian air yang baik, ditunjukan dengan ada tidaknya usaha ilegal apa bila terjadi kekurangan air pada petani. Hasil penelitian menunjukkan bahwa indikator pelayanan air irigasi cukup baik malaupun belum memuaskan. Kurang lancarnya sistem pembagian air kelahan sawah mengakibatkan kontinuitas air juga berkurang sehingga sebagian petani mengeluh karena kekurangan air. Hal ini didukung adanya kontruksi irigasi yang tidak tepat dan tidak sesuai dengan kondisi lahan sawah petani sehingga sistem pengairan irigasi belum berjalan merata dan adil.Kondisi ini sampai membahayakan lahan sawah yang akibatnya lahan bertambah masa dan dapat menurunkan hasil produksi padi. Petugas irigasi dan petugas desa berusaha untuk meminimkan hambatan ini agar cara pembagian air dapat dilaksanakan sebaik-baiknya [4].

Pembagian tanggung jawab pemeliharaan rutin pada saluran primer/sekunder dan saluran tersier haruslah berdasarkan koordinasi $\mathrm{P}_{3} \mathrm{~A}$ setempat dengan bermusyawarah dengan seluruh petani anggotannya.Meningkatkan produksi dan nilai jual tanaman.
1) Produksi dari hampir semua jenis tanaman akan meningkat, dengan adanya pemberian air yang tepat waktu dan tepat jumlah.

2) Dengan melakukan percobaan-percobaan kita dapat mengetahui kebutuhan air yang opotimum untuk suatu jenis tanaman pada daerah tertentu, sehingga dapat dihasilkan tingkat produksi tanaman yang paling maksimum.

3) Pemberian air yang kurang ataupun melebihi jumlah air yang diperlukan akan menurunkan tingkat produksi tanaman tersebut.

4) Ketika ketersediaan air terjamin secara terus menerus, maka tanaman-tanaman yang unggul /lebih baik secara alamiah akan mengungguli tanaman yang kurang baik, sehingga yang tertinggal adalah tanaman-tanaman yang unggul yang lolos dari seleksi alam. Dengan demikian hasil produksinyapun akan lebih baik dalam hal kualitas.

5) Dengan kualitas produksi yang lebih baik akan meningkatkan nilai jual dari tanaman tersebut.

6) Berkurangnya/menghilangnyatanaman campuran (Mixed Cropping).

Petani dan pengurus $\mathrm{P}_{3} \mathrm{~A}$ hendaklah selalu melakukan pemantauan dan pengawasan jaringan irigasi agar dapat diketahui anggota yang patuh dan tidak dalam pemeliharaan jaringan irigasi yang menjadi tanggung jawabnya. Sebaiknya untuk mempermudah pemantauan dan pengawasan pada saluran ditulis nama petani yang bertanggung jawab terhadap pemeliharaan rutin jaringan irigasi. Petani anggota $\mathrm{P}_{3} \mathrm{~A}$ dan pengurus $\mathrm{P}_{3} \mathrm{~A}$ hendaknya selalu menambah wacana dengan diskusi/dialog dengan penyuluh/petugas lapangan agar dapat memperoleh ide-ide atau pemikiran yang dapat mempermudah pelaksanaan pemeliharaan rutin jsaringan irigasi oleh petani anggotanya.

Bagi petani yang telah ditentukan untuk menanam palawija akan tetapi petani tersebut melakukan penanaman padi disebut padi gadum gelap. Jatah air bagi padi adalah sama dengan jatah air untuk palawija, akan tetapi jika ketersediaan air ternyata masih ada sisanya padi tersebut diberikan juga air yang cukup, sesuai dengan kebutuhan untuk tanaman padi. Dari kondisi tersebut, maka dapat ditarik kesimpulan manajemen operasional irigasi yang diterapkan pada daerah irigasi [5] adalah:

1) Prosedur alokosi air ke jaringan tersier adalah imposed atau arranged, karena terdapat penerapan pola dan tata tanam yang telah ditetapkan oleh otoriti (PU Pengairan).

2) Metode air ke jaringan tersier dan distribusi air di jaringan utama adalah splitted flow, karena air diberikan secara terus menerus sesuai dengan kebutuhan dan besarnya debit sesuai dengan luas areal tanam. Pada saat musim kering atau kemarau distribusi air pada jaringan utama berubah menjadi rotation flow.

3) Sistem kontrol aliran adalah proposional kontrol, dimana air diberikan secara proposional dengan besar debit yang di berikan berdasarkan luas areal tanah. 


\subsection{Dampak Keberadaan Irigasi di Desa Jatisela}

Berdasarkan hasil wawancara dengan 30 petani responden yang ada di dua dusun; Johar Pelita dan Griya Praja Asri di Desa Jatisela Kecamatan Gunung Sari dan hasil analisa data tentang evaluasi sistem irigasi dan drainase pada daerah irigasi untuk 3 parameter yang diamati pada penggunaan irigasi, yakni; pemahaman teknik, dampak ekonomi, dan dampak sosial.

\subsection{Pemahaman Teknis}

Berkaitan dengan pemahaman teknis petani dalam memanfaatkan jaringan irigasi tersier dilakukan dengan melakukan wawancara dan observasi.

Pemahaman teknis petani dalam pertanian sangat mempengaruhi pengetahuan, pengalaman, keterampilan petani pengguna irigasi.Dari hasil wawancara dengan 30 responden menurut pemahaman teknis petani menguraikan atau gambaran mengenai pemahaman teknis petani yang menjadi sampel tentang penelitian ini. Deskripsi karakteristik responden menurut pemahaman teknis petani dapat di lihat pada tabel berikut:

Tabel 1.

Evaluasi sistem irigasi dan drainase pada parameter pemahaman teknis petani.

\begin{tabular}{|c|c|c|c|c|c|c|}
\hline \multirow{2}{*}{ Pemahaman Teknis } & \multicolumn{3}{|c|}{ Jumlah Responden } & \multicolumn{3}{|c|}{ Persentase } \\
\hline & 1 & 2 & Total & $\mathbf{1}$ & 2 & Total \\
\hline Mengetahui Irigasi & 30 & - & 30 & 100 & - & 100 \\
\hline Kapan irigasi ada & 30 & - & 30 & 100 & - & 100 \\
\hline Sistematika pembagian & 28 & 2 & 30 & 93 & 7 & 100 \\
\hline Pemanfaatan irigasi & 27 & 3 & 30 & 90 & 10 & 100 \\
\hline Rata-rata & 28.75 & 1.25 & - & 95.75 & 4.25 & - \\
\hline
\end{tabular}

Keterangan : 1) Mengetahui; 2) Tidak Mengetahui

Berdasarkan tabel 1 menunjukkan bahwa pada pemahaman teknis petani dengan komponennya pengetahuan tentang irigasi, keberadaan irigasi, pembagian air irigasi, dan pemanfaaatan irigasi di peroleh sebagai berikut.Secara keseluruhan atau sebanyak 30 orang (100\%) petani responden mengetahui keberadaan irigasi di daerahnya dikarenakan jaringan irigasi melewati lahan petani responden.Selanjutnya sebanyak 30 orang atau $100 \%$ petani responden mengetahui kapan irigasi dilokasi mulai dibangun. Hal ini dikarenakan keterlibatan masyarakat untuk proses pembangunan dilakukan oleh masyarakat setempat untuk mengairi lahan yang akan diari para petani responden dari hasil yang sudah di peroleh sebesar 100\% yang mengetahui keberadaan irigasi.

Selanjutnya sebesar $100 \%$ responden mengetahui sejarah keberadaan irigasi dilokasi peneliti.Menurut responden irigasi di daerahnya dibangun pada tahun 1989 dengan tujuan menampung air hujan yang seringkali hilang dikarenakan evaporasi yang tinggi dan aliran air menuju kepantai yang sangat cepat.

Pada tabel 1 kolom 3 mencapai 93\% atau setara dengan 28 orang responden mengakui bahwa sistem pembagian air irigasi dilakukan oleh petugas $\left(\mathrm{P}_{3} \mathrm{~A}\right)$, sedangkan $7 \%$ atau setara dengan 2 orang lainnya dengan sistem pembagiannya melakukan sendiri tanpa ada petugas yang membantu. Petugas P3A tersebut merupakan anggota kelompok tani pemakai air irigasi. Berdasarkan ketentuan yang ada bahwa masyarakat bertanggungjawab terhadap pengelolaan dan pemeliharaan jaringan irigasi tersier dan drainase yang ada dan pengelolaan system irigasi tersier dan drainase air bila dilakukan secara kolektif dan terjadwal akan mengurangi resiko konflik dalam perebutan pemanfaatan air irigasi.

Selanjutnya terhadap pemanfaatan irigasi, 90\% responden atau setara dengan 27 orang responden memanfaatkan jaringan irigasi tersier pada saat musim hujan saja sedangkan10\% responden atau setara dengan 3 orang responden lainnya menggunakan diesel untuk mendistribusikan air ke lahan mereka pada musim hujan.

Di lokasi penelitian tidak terdapat bangunan bagi air, dimana bangunan bagi merupakan bangunan yang berfungsi untuk membagi air dari saluran primer atau saluran sekunder kedua buah saluran atau lebih yang masing-masing debitnya lebih kecil. Hal ini mempengaruhi dalam pendistribusian air irigasi secara merata dan suatu saat akan menyebabkan terjadinya konflik perebutan air. Memang diakui oleh responden bahwa terdapat lembaga yang disebut $\mathrm{P}_{3} \mathrm{~A}$ sebagai pengelola dan pemelihara jaringan irigasi tersier yang ada, namun tidak menutup kemungkinan akan terjadi hal-hal yang tidak diinginkan apabila petugas $\mathrm{P}_{3} \mathrm{~A}$ tidak mampu membagi air secara merata maka akan menyebabkan kecemburuan sehingga dapat konflik akan terjadi.

Walalupun kondisi saluran di Desa Jatisela Kecamatan Gunung Sari Kabupaten Lombok Barat adalah masih kurang terawat dalam memelihara saluran irigasi. Namun telah disepakati bahwa pemeliharaan rutin saluran dilaksanakan sebulan sekali dan iuran anggota dibayarkan setelah petani responden melakukan panen.Pembayaran dilakukan berdasarkan jumlah kebutuhan air dan luas lahan yang dimiliki.

Kemudian debit air yang diperoleh petani untuk mengairi sawah mereka kebutuhannya berdasarkan rumus berikut :

Ket:

$$
\mathrm{Q}=\mathrm{A} \times \mathrm{V}
$$

$\mathrm{V}=$ volume air (meter perkubik)

$\mathrm{A}=$ luas penampang

$\mathrm{Q}=$ debit air (meter kubik/s)

Berdasarkan observasi diperoleh bahwa debit air pada saluran irigasi tersier di Desa Jatisela sebesar 0,101 m/s. Artinya bahwa debit air yang ada 
masih sangat rendah (sedikit) hal ini pasti akan mempengaruhi penggunaan yang terdistribusi merata bagi petani responden.

\subsection{Dampak Ekonomi}

Ekonomi sangat berpangaruh terhadap kesejahteraan rumah tangga para petani.Secara teori bahwa semakin kecil lahan yang dimiliki untuk usahatani maka semakin kecil pendapatan yang diperoleh. Lahan yang dimiliki oleh masing-masing petani responden rata-rata sebesar 0,1 $\mathrm{Ha}$. hal ini tentunya berpengaruh terhadap pendapatan petani. Apalagi jenis tanaman yang diusahakan masih sangat terbatas pada padi, palawija, dan jagung.

Dalam penelitian ini dampak ekonomi dari pemanfaatan jaringan irigasi tersier dilihat dari dua parameter, yakni jenis tanaman yang diusahakan dan keuntungan yang diperoleh. Adapun hasil rekapitulasinya sebagaiberikut:

Tabel 2.

Evaluasi sistem irigasi terhadap Dampak Ekonomi

\begin{tabular}{|l|c|c|c|c|c|c|}
\hline \multicolumn{1}{|c|}{ Dampak Ekonomi } & \multicolumn{3}{c|}{ Jumlah Responden } & \multicolumn{3}{c|}{ Persentase } \\
\cline { 2 - 7 } & $\mathbf{1}$ & $\mathbf{2}$ & Total & $\mathbf{1}$ & $\mathbf{2}$ & Total \\
\hline Tanaman apa saja yang di tanam & 21 & 9 & 30 & 70 & 30 & 100 \\
Keuntungan yang di peroleh & 17 & 13 & 30 & 57 & 43 & 100 \\
\hline Rata-rata & 19 & 11 & - & 63.5 & 36.5 & - \\
\hline
\end{tabular}

Keterangan : 1) Mengetahui; 2) Tidak Mengetahui

Berdasarkan tabel 2 menunjukan bahwa sebesar $70 \%$ responden setara dengan 21 orang responden yang menanam padi saja. pada saat menanam padi petani merasa untung sekitar 50-60 karung dalam 1 ha pada saat musim hujan dalam satu kali panen dan dalam 1 are sawah petani bisa 4-7 karung padi pada saat musim hujan dalam 1 kali panen, sedangkan 9 orang lainnya atau mencapai sebesar 30\% tidak menanam padi dan mereka menanampalawija. Karena para petani mengaku pada saat menanam padi mereka merasa untung sebab tanaman padi merupakan sumber kehidupan setara dengan kebutuhan air bagi kehidupan manusia. Dan pada kolom kedua mencapai sebesar $57 \%$ responden setara dengan 17 orang yang mengaku untung, dalam 1 ha sawah pada saat panen mencapai 50-60 karung atau sekitar 4 ton sampai 5 ton padi dan ketika petani menjual hasil panennya keuntungan yang di peroleh mencapai 11 juta, sedangkan 13 orang lainnya atau setara dengan $43 \%$ yang mengaku rugi dan kerugian yang di peroleh dalam 1 ha bisa mencapai sebanyak 15-20 karung atau setara dengan 2,5 juta kerugian yang di peroleh petani sebab pada saat menanam atau saat pertumbuhan tanam memerlukan air untuk mengairi lahannya sedangkan para petugas $\left(\mathrm{P}_{3} \mathrm{~A}\right)$ kalau membagi air ke lahan para petani mereka tidak meninjau langsung ke lahan para petani.

Dampak keberadaaan irigasi bagi petani secara ekonomi terlihat dari hasil produksi padi meningkat dengan menggunakan irigasi dalam 1 ha sawah sebanyak 50-60 karung, sedangkan produksi palawija (kedelai, jagung, sayuran) menggunakan irigasi dalam 1 ha sawah sebanyak 10-15 karung kedelai, sedangkan jagung 1-2 ton, dan sayuran yang di peroleh sebanyak 1-3 kali panen.

Terjadi interaksi kegiatan irigasi dengan teknologi lainnya dalam mendukung produktivitas usahatani, menyebabkan peran irigasi tersebut tidak secara eksplisit dapat diidentifikasi dampaknya terhadap peningkatan produksi.Hal tersebut, [6] secara empiris di lapangan ditunjukan dengan perolehan produktivitas usahatani padi. Hasil penelitiandi daerah irigasi Pekasih Kabupaten Kulonprogo Yogyakarta, bahwa dalam periode tahun 2002-2003, perolehan produksi padi per hektar tara-rata terjadi peningkatan relatif kecil yakni dari 5,68 ton per hektar pada tahun 2002 menjadi 5,70 ton per hektar pada tahun 2003 atau meningkat sekitar 0,02 ton per hektar.

\subsection{DampakSosial}

Dari segi dampak sosial sangat memngaruhi pengetahuan, keterampilan serta sikap seseorang dalam bermasyarakat, bersosial, kelembagaan selain dapat menambah wawasan dalam berlembaga di suatu masyarakat.Deskripsi responden menurut dampak sosial berdasarkan empat parameter; peran petani dalam pemeliharaan, kelembagaan, manfaat sosial, dan tindakan pencegahan terhadap penyumbatan irigasi. Deskripsi karakteristik responden menurut dampak sosial sebagai berikut:

Tabel 3.

Evaluasi sistem irigasi terhadap Dampak Sosial

\begin{tabular}{|l|c|c|c|c|c|c|}
\multicolumn{1}{|c}{ Dampak Sosial } & \multicolumn{2}{c|}{ Jumlah Responden } & \multicolumn{3}{c|}{ Persentase } \\
\cline { 2 - 7 } & $\mathbf{1}$ & $\mathbf{2}$ & Total & $\mathbf{1}$ & $\mathbf{2}$ & Total \\
\hline Peran petani dalam memelihara saluran & 30 & - & 30 & 100 & - & 100 \\
Apakah ada kelembagaan & 30 & - & 30 & 100 & - & 100 \\
Manfaat secara sosial yang anda peroleh & 16 & 14 & 30 & 53 & 47 & 100 \\
Tindakan yang dilakukan apabila saluran tersumbat & 29 & 1 & 30 & 97 & 3 & 100 \\
\hline Rata-rata & 26.25 & 3.75 & - & 87.5 & 12.5 & - \\
\hline
\end{tabular}

Keterangan : 1) Ada; 2) Tidak Ada

Berdasarkan tabel 3 menunjukkan bahwa 100\% responden atau setara dengan 30 orang responden mengakui terdapat peran petani dalam memelihara saluran irigasi dan drainase. Perananan tersebut ditunjukkan dengan melakukan kegiatan gotong royong.Gotong royong dilakukan petani khusus untuk memelihara saluran irigasi dan 
drainase.Kegiatan tersebut juga dilakukan secara bersama dengan para petugas.Biasanya kegiatan gotong royong dilakukan terjadwal, yakni dua minggu sekali.

Partisipasi petani/P3A pada kegiatan pemeliharaan rutin pada saluran primer, sekunder dan tersier disarankan dilakukan dengan membagi dan memberikan tanggung jawab terhadap petani pemilik/petani penggarap didasarkan atas perbandingan luas pengelolaan lahan sawah masing-masing, sehingga diperoleh azaz keadilan, dimana yang mendapatkan manfaat lebih besar/dibudayakan lebih besar akan mendapatkan bagian tanggung jawab pemeliharaan rutin yang lebih besar pula.

Pada tabel 3 kolom kedua menunjukan bahwa $100 \%$ responden atau setara dengan 30 orang responden mengakui terdapat kelembagaan yang khusus memelihara saluran irigasi. Kelembagaan tersebut terdiri dari $\mathrm{P}_{3} \mathrm{~A}$, petani, dan aparat desa.Kegiatan memelihara saluran irigasi dan drainase dilakukan secara kolektif.Hal ini sebagai upaya mencegah terjadinya kecemburuan sosial sehingga konflik dapat dicegah.Keterlibatan semua elemen masyarakat secara sosial berpengaruh terhadap kehidupan sosial masyarakat, dikarenakan masyarakat telah mengetahui mana yang menjadi hak dan kewajiban.

Pada daerah yang sudah memiliki kelembagaan pengelolaan irigasi tradisional yang kuat akan berdampak pada perselisihan kepentingan sehingga melemahkan ikatan sosial yang ada di masyarakat. Padahal, kelembagaan pengelolaan irigasi tradisional justru memiliki kearifan local (local wisdom) yang mengakar pada petani.Bentuk kekuatan kelembagaan ini karena telah menjadi system di masyarakat sebagai bentuk perpaduan antara budaya dan norma. System irigasi tradisional meskipun terlihat teknologi yang sederhana tetapi memiliki nilai ekonomis yang tinggi, tata kelolanya sudah modern karena humanis melibatkan semua anggota secara demokratis, serta memiliki para anggota memiliki ikatan yang kuat.

Selanjutnya pada kolom ketiga apakah ada manfaat secara sosial yang anda peroleh dengan keberadaan jaringan irigasi, sebesar 53\% responden atau setara dengan 16 orang responden terdapat manfaat sosial yang diperoleh. Manfaat yang diperoleh terdiri dari peningkatan kesejahteraan petani, kebersamaan petani, jaringan kelembagaan yang kuat, dan tingkat partisipasi yang meningkat.Sedangkan $47 \%$ responden atau setara dengan 14 orang mengaku tidak ada manfaatnya hanya secara sosial.Pengakuan tersebut didasari atas pandangan masyarakat yang masih menganggap bahwa seharusnya pemerintah turun tangan langsung dalam melakukan pemeliharaan jaringan irigasi dan drainase.

Dengan didukung realitas bahwa pertanian mampu menggerakkan kelas bawah dan sektor ekonomi rill, maka sudah barang tentu apabila pemerintah berpihak pada mayoritas rakyatnya, kebijakan yang diambil adalah dengan memeberikan kesempatan yang besar terhadap petani untuk mengelola sektor irigasi.keuntungan juga akan kembali pula pada Negara bahkan dengan nilai yang tidak bisa diukur dengan uang sekalipun. Kekuatan capital sosial masyarakat akan semakin kokoh dan kuat. Kepercayaan masyarakat terhadap pemerintah juga akan meningkat karena petani telah diberikan kepercayaan untuk mengelola apayang menjadi kepentingannya. Penataan kelembagaan pengelolaan irigasi Berdasarkan PP No. 20 Tahun 2006 tentang irigasi yang merupakan aturan operasional UU nomor 7 tahun 2004 tentang Sumber Daya Air, bahwa kelembagaan pengelolaan irigasi meliputi Instansi pemerintah yang membidangi irigasi, P3A dan Komisi Irigasi [5].

Hal ini disebabkan pemerintah masih menganggap petani sebagai objek pembangunan yang tidak punya kecakapan dan kemampuan dalam irigasi.Padahal nyatanya, jauh sebelum pembangunan jaringan irigasi massal, petani lah yang mula-mula mempunyai kemampuan utnuk merencanakan, mengelola, mengontrol sampai dengan mendirikan organisasi kelembagaan tradisional.

Kemudian pada kolom keempat tindakan yang dilakukan apabila ada saluran tersumbat menunjukan bahwa dari 29 responden hanya 97\% atau setara dengan 29 orang melakukan gotong royong ketika saluran tersumbat. Partisipasi petani dalam memelihara saluran irigasi dan drainase dilakukan secara rutin dua kali dalam sebulan.Tingkat kesadaran dari petani dalam membuang sampah, petani tidak lagi membuang sampah di dekat salurandikarenakan tindakan tersebut dapat menyebabkan sumbatan dan pada saat musim hujan biasanya jalan sekitar irigasi tergenang.

\section{SIMPULAN DAN SARAN}

\section{Simpulan}

Berdasarkan hasil penelitian dan pembahasan diatas maka diperoleh simpulan sebagai berikut :

1. Secara teknis diloksi penelitian tidak ada bangunan pembagi air irigasi, debit air sangat rendah sebesar $0,101 \mathrm{~m} / \mathrm{s}$, dan terdapat sistem distirbusi air yang dilakukan oleh Petugas $\mathrm{P}_{3} \mathrm{~A}$.

2. Dampak ekonomi sebesar 57\% responden mengakui memperoleh keuntungan dengan keberadaan irigasi. Keuntungan yang di peroleh mencapai 11 juta dalam setiap panen.

3. Secara sosial terdapat peran petani dalam memelihara saluran, kelembagaan petani sangat kuat, dan tingkat partisipasi meningkat.

4. Ditemukan distribusi air yang tidak merata disebabkan karena adanya jaringan irigasi yang rusak dan pemeliharaan yang kurang.

\section{Saran}

Dari uraian dan simpulan diatas maka dapat diajukan saran sebagai berikut :

1. Diperlukan peran aktif $\mathrm{P}_{3} \mathrm{~A}$ dalam memelihara dan mengelola air irigasi untuk menghindari konflik perebutan air oleh petani.

2. Bagi peneliti selanjutnya lebih fokus pada masalah teknis jaringan irigasi untuk melengkapi penelitian sebelumnya. 
Jurnal Agrotek Ummat, Vol. 4 No.2, Agustus 2017 / Evaluasi Sistem Irigasi Tersier Pada Daerah Irigasi Meninting di Desa Jatisela Kecamatan Gunung Sari Kabupaten Lombok Barat/ Budy Wiryono, Suwati, dan Marianah.

\section{DAFTAR RUJUKAN}

[1]Nugroho, I. A., 2010, Pengairan Pertanian dan JaringanIrigasi Baru.Ghalia Indonesia. Jakarta

[2] Sugihan, B. T., 1996, Pengaturan Pemakaian AirIrigasi. PT. Remaja. Bandung.

[3]Anonim, 2013. Profil Desa Jatisela.Pemerintahan Desa Jatisela. Lombok Barat.

[4] Suparmoko, 1980, Persepektif Sosioteknik dalamPembangunan Irigasi Kecil Unand.Padang.

[5] Anonim, 2007. PP No. 20 Tahun 2006 tentang irigasi. Direktorat Jenderal Pekerjaan Umum. Jakarta.

[6] Dewi, Y. A. dan Rachmat, H., 2003, Kajian Efesiensi dan Efektifitas Operasional Jaringan Irigasi Mendukung Produktivitas Usahatani Padi Sawah, Balai Besar Pengkajian dan Pengembangan Teknologi Pertanian, Bogor, pp. 1 - 4 . 